\title{
CONVERGENCE IN PRICE LEVEL AMONG EAST JAVA'S REGIONS
}

\section{Rifai Afin ${ }^{1}$}

\begin{abstract}
A bstraksi
Penelitian ini berupaya menjelaskan konvergensi tingkat harga di wilayah Jawa Timur. Analisa konvergensi harga ini dilakukan dengan dua metode, pertama dengan metode regresi cross sectional, dan kedua dengan mempergunakan prosedur Augmented Dickey Fuller. Selain itu pengembangan metodel dilakukan dengan mempergunakan teknik analisa panel yang dikembangkan oleh Levin dan Lin (1992, 1993).

Hasil pengujian untuk selang periode 1983-2003 menunjukkan bahwa konvergensi inflasi tidak terjadi. Untuk periodel 1983-1993 dan 1994-2003, hasil pengujian menunjukkan arah yang sesuai dengan teori, dan signifikan

However, test using data from 1983-2003 show that inflation convergence across East Java Regions does not occur consistently over time. Separately period, 1983-1993 and 1994-2003 we found right sign and significant in total period but in small sample period, 1983-1993 and 1994-2003 we also found the right sign but insignificant. In the context of development of monetary policy, the evidence suggest if the convergence in national data of price level can bring monetary policy becoming similar across regions.
\end{abstract}

Keywords: Regional, price level, convergence, panel unit root test.

JEL Classification: C23, E31, R11, R51, R58

1 The author is a researcher on the Center for Urban and Regional Studies (CURES) and the Regional Economic Development Institute (REDI), Surabaya-Indonesia. Contact: rifai_ai@yahoo.com 


\section{INTORDUCTION}

Since the beginning of the Decentralization era, the regional issue has been crucial in the Indonesian policy. It is Obvious that the size and the geography of the country lead to emphasize the role of the regions. Moreover, Indonesia has very hierarchical administrative organization. The impact of the relaxation of the central government control gave a more responsibilities to the regions. The reform has altered the relationship between center and regions since the rule of government on the Law 22 / 1999 about regional government and the rule of government on the Law 25 / 1999 about the balance of financial central government and regional government. There are several implications, first, the central government has moved from the controlled policy through direct administration of the economy, to the form of macro-economic management (Goodman and Segal, 1994). Second, the fiscal relationship between the center and the regions changed drastically, and gives a higher power to the regions (Brun, 2002).

The power transition may greatly influence the monetary policy regarding the link between the direct link between the central bank and the local government. The Bank of Indonesia now is more difficult to control regional inflation in Indonesia because each region has a more various power to influence the regional inflation. The occurrence of a currency and the trade area which integrate all regional markets should theoretically guarantee the convergence of inflation rates across participating regions. In this context, some of the broadly known impediments to the purchasing power parity to hold will disappear. The factors like the trade barriers, the nominal exchange rates fluctuation and the transportation cost are now nil or negligible.

Because the heart of decentralization is giving a higher role on the district or the municipal level, then we should investigate the inflation dispersion at this level. In this paper, we raise the issue of the inflation dispersion across regions in East Java Indonesia and its implication for the Central Bank of Indonesia policy in several ways. First, we will shed some light on the dynamics of the regional inflation rates by testing the existence and the degree of their mean reverting behavior. This allows us to address the issue of whether the existing of cross-regional differentials should be a major issue for the policy makers. Particularly we are interested whether overall dispersion has decreased over time ( $\beta$-convergence) or not.

The rest of the paper is organized as follows; section 2 will discuss the theoretical review about the price level convergence. Section 3 will highlight the data and the methodology. Section 4 gives the result and the sensitivity analysis, while the conclusion will be the last session. 


\section{THEORY}

Brun, Combes, and Renard examine regional spillovers can emerge from three types of externalities:

1. Demand side externalities, in the sense that the marginal productivity of the capital depends on the beliefs of the region's investors about the demand in other regions, especially in the regions with the highest level income per capita.

2. Trade externalities because the trade is more intensive when the transaction costs are decreasing. On the other hand, the higher income per capita, the higher the domestic trade among the regions in all East Java. The further implication will be on the growth of the regions.

3. Supply side externalities resulted from the technical knowledge and the managerial skill diffusion. In the long term growth perspective, we may expect such externalities and its predominance will exist.

Supply spillovers may be channeled by domestic trade among East Java's regions.

Technological innovations embodied in foreign capital goods (Grossman and Helpman, on Brun, 1991) diffuse to one region from another region imports. Moreover, the competition on East Java's regions may incite the producers in a region to adopt the technology of another regional producer.

Another important channel is the Foreign Direct Investments (FDI), as the domestic firms are possible to imitate the technologies created by the foreign firms (de Mello, 1997). The more open the region, the more likely they can capture the benefit of the FDI, either by learning by doing, technological transfer, intermediate goods and the access to foreign markets. Some firms notably from inland regions, may relocated part of their production process to get the same benefits. This is the way one region may diffuse this type of externalities to another region.

However, the theory of the regional price level convergence is still debatable. Balassa and Samuelson contribute on the international economics debate about the validity of the PPP. They argue that the exchange rate determination introduces systematic bias into the relationship between the relative prices and the exchange rate. Even earlier, Harrod referred to the role of non-tradable goods as a potential source of deviation from PPP. By classifying the tradable and non-tradable goods and under the assumption of the law of one price, HarrodBalassa-Samuelson hypothesis explains that the differentials in productivity growth between the two sectors may lead to inflation differentials within a given country by altering the internal price structure. Thus if the differentials in consumer price inflation increase across the regions 
or countries of monetary union, then it must be because of the differences of non-traded goods prices.

Why would such inflation differentials in the non-traded goods prices arise? Based on Neary (1988), any factors which alter the relative supply and demand of non-traded goods could generate the inflation differentials across monetary union. The share of the non-traded goods prices within a region will depend on the pace of productivity growth in the traded sector relative to the non-traded productivity. The more rapid productivity growth of the traded sectors the faster the general increase the wage. Equivalently, the slower the productivity growth in the non-traded sector, the higher the non-traded goods prices. Two basic predictions of the standard Harrod-Balassa-Samuelson may be summarized as follows; (i) the sectoral productivity differentials determine the price differentials of the non-tradable goods relative to tradable one, and (ii) the differences in the relative price of the non-tradable leads to a deviation from the PPP.

The theory discussed above support the evidence of consumer's price differential across regions. Considering the speed of adjustment, the most natural attempt to explain the slow adjustment of the relative price is the absence of the non-traded goods in the CPI indices used.

Recalling that $P_{0}$ is the logarithm of the relative price of the city $i$ with respect to our numeraire city 0 at time $t$, i.e. $p_{i t}=\log \left(P_{i t} / P_{0 t}\right)$ we can express the price levels of city $i$ and 0 as a weighted average of the tradable and the non-tradable goods below,

$$
\begin{aligned}
& P i t=(1-\gamma) P_{i t}^{T}+\gamma P_{0 t}^{N T} \\
& P o t=(1-\gamma) P_{0 t}^{T}+\gamma P_{0 t}^{N T}
\end{aligned}
$$

In two equations above, we have assumed that the share of the non-tradable goods on the overall price $\gamma$ is homogenous across regions. Substituting (1) and (6) into the relative price definition and arranging the expression, we obtain that logarithm of the real exchange rate is

$$
P i t=\ln \left(\frac{P_{i t}^{T}}{P_{0 t}^{T}}\right)+\gamma \ln \left(\frac{P_{0 t}^{T}}{P_{0 t}^{N T}}-\ln \frac{P_{i t}^{T}}{P_{i t}^{T}}\right)
$$

Assume the PPP holds for the traded goods. The first term in (3) has to be I(0). Thus the non-stationarity of the second term in equation (3) leads to a real exchange rate deviation. According to the Harrod-Balassa-Samuelson hypothesis, the evolution of the relative price of the non-tradable goods reflects the productivity bias across the two sectors. To be more explicit, the following equation relates the relative price of the non-tradable goods of city $i$ and its sectoral productivity differential, 
$\ln \left(\frac{P_{i t}^{T}}{P_{i t}^{N T}}\right)=\ln \left(\frac{\alpha^{N T}}{\alpha^{T}}\right)+\ln \left(\frac{\theta_{i t}^{N T}}{\theta_{i t}^{T}}\right)$

$\alpha^{j}$ is the labor share in sector $\mathrm{j}$ and $\theta$ is the labor productivity in sector $j$. We may extend the specification to reflect the persistent differences in the evolution of the sectoral wages. The labor may in fact be non-homogeneous due to the differences in skills or human capital and when the labor utilization is below its full employment level. Hence equation (4) can be extended to include the relative wage differentials as an additional explanatory variable, under the implicit rejection of the uniformity in relative nominal wages.

\section{DATA AND METHODOLOGY}

\section{III.1ß DATA}

The source of the data is East Java Central Bureau of Statistics (BPS), which collect at a regional level Regional Income Deflator with a relatively high level disaggregated. The initial dataset is a panel of yearly observations on East Java region Regional Deflator over the period 1983 - 2003 and 1983 as basic year. A monthly data for these regions are not available for all regions but only four regions which is central bank of Indonesia surveyed. Plotting the Regional Income Deflator, Surabaya, rural region and cities region separately, all of the Nature of Regional Income Deflator seems to be upward trended. There is also evidence of high volatility in the crisis period between 1997-2003.

In the spirit of the empirical growth literature, we are using regionally disaggregated data to examine the question of inflation diversity and convergence in East Java, Indonesia Regions. There are several reasons that make such an approach desirable. The most obvious one is, that it enables us to increase the number of observation and thus to obtain more precise statistical results. For the case of East Java any cross sectional examination with rural and cities data would be based on twenty eight rural and eight cities observations.

Plotting the relative price of each of the regional prices on numeraire city, Surabaya, two groups of our data we demonstrated separately with rural regions and cities regions. Some of the series seems to be fluctuating, especially after crisis period. An idea of the price convergence in relative price over the whole sample can be deduced plotting the price of each of the 36 regions relative to their cross-sectional average. In figure 2.3 and 2.4 the deviations from this numeraire city are displayed. There is also evidence of high volatility in the crisis period, 19972003. This is as fluctuating as yearly regional price level especially after crisis, but has no trend effect like yearly price level. 


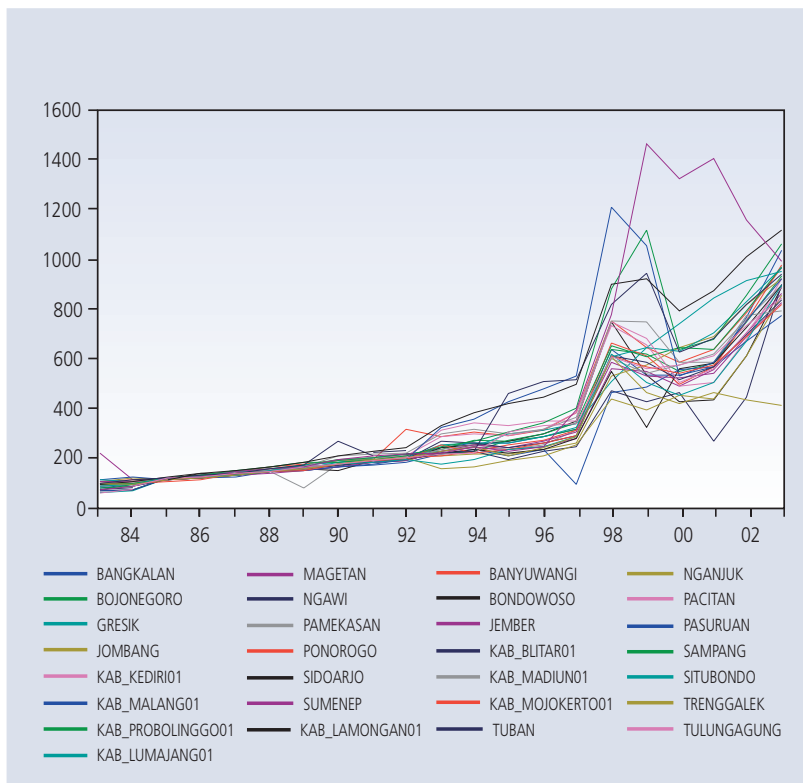

Figure III.1. Yearly Rural Income Deflator

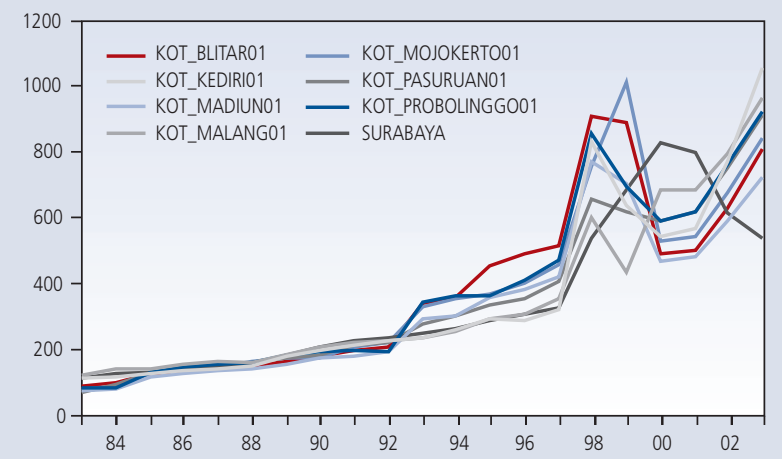

Figure III2. Yearly Cities Income Deflator 


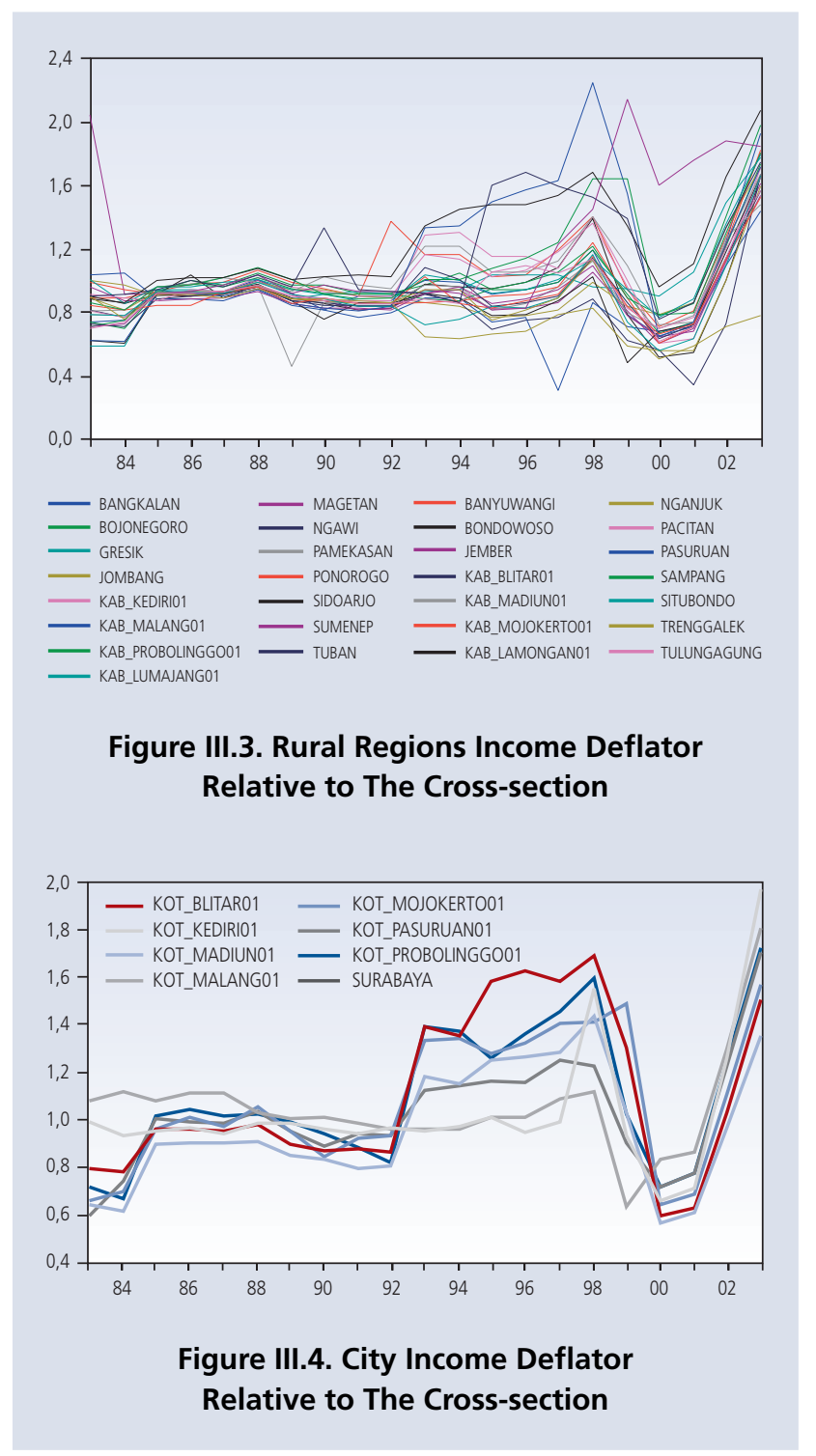

The picture suggest that all of relative prices in East Java region either rural and cities seem to converge.

\section{III.2 METHODOLOGY}

Test for mean reverting behavior ( $\beta$-convergence) in inflation rates, we are using several different procedures. The most popular approach particularly in the literature on relative prices - is to use Augmented Dickey - Fuller tests. To increase precision, recent studies apply panel 
techniques developed by Levin and Lin (1992) and Levin and Lin (1993). We will turn to this methodology in the next section. Before, we will present results from an approach that has been intensively used in the empirical growth literature. We think that it can be very helpful for our purposes - particularly, since there are large similarities not only with respect to the nature of the data we use but also with the respect to the question under consideration. Additionally, the methodology provides us with some measure of how fast convergence occurs. In analogy to the growth literature, we test for inflation convergence by setting the average change in inflation rates over the considered sample period in relation to its initial value by estimating regression of the type :

$$
\frac{1}{T} \Delta \pi_{i, t 0+T}=\text { cons } \tan t+b^{*} \pi_{i, t o}+\varepsilon_{i, t o, t o+T}
$$

$T$, denotes the length of the sample period in years, $\pi$ denotes the inflation rate computed as an average annual rate and to denotes the initial period. $\frac{1}{T} \Delta \pi_{i, t o+T}=\frac{1}{T}\left(\pi_{i, t o+T}-\pi_{i, t o}\right)$ denotes the average change in the inflation rate over the sample period. $\varepsilon_{i, t o, t o+T}$ represents an average of the error terms $\varepsilon i, t$ between to and to $+T$. The estimation is done using OLS.

If there is convergence in inflation rates, the estimated value for $b$ will be negative. This would imply that prices of a country with an initially relatively high inflation rate would increase more slowly (or decrease faster) in the subsequent period than those of a country with an initially relatively low inflation rate. Thus, the existing inflation rate gap would diminish. As an extreme case, one could even imagine that 'leapfrogging' or 'convergence overshooting' occurs, i.e., that an existing inflationary gap not only diminishes but reverses in sign. As we will see, this actually happens in our sample and has important impacts for the short-run analysis. The estimated value for the slope coefficient b in equation (2) can be used to compute a rough measure of the convergence speed. Using an expression that is analytically derived in the growth literature, an estimate for the convergence rate can be obtained by solving the expression:

$$
b=-\left(\frac{1-e^{-\beta * T}}{T}\right)
$$

For $\beta$ using the estimated value for $b$ from equation (1). The so derived value for $\beta$ gives an estimate of the proportion by which an existing inflationary gap is reduced in each period. A problem that arises in the interpretation of this coefficient is that unlike in the growth literature - the identity given in equation (2) cannot be derived in the stringent theoretical way. Nevertheless, as a comparison of the results in this and the next section shows, its use turns out to be very illustrative. 
In this section, we want to investigate about the inflation convergence a little further by using an alternative methodology that makes more explicit use of the time series dimension of our data. Due to the shortness of our sample period, an analysis of individual inflation series does not seem to be reasonable. However, exploiting the large number of cross sectional units, we can pool the data and use panel data econometric methods. In analogy to the Purchasing Power Parity literature. We examine the mean - reverting behavior of inflation rates using the panel unit root framework developed by Levin and Lin (1992) and Levin and Lin (1993).

Given our sample of inflation rates $\pi i, t$ (with $\mathrm{i}=1,2, \ldots, \mathrm{N}$ denoting the individual regions of our sample and $t=1,2, \ldots, T$ ) representing the time index), the test for inflation convergence is based on the following equation:

$$
\Delta \pi_{i, t-1}=\rho \pi_{i, t-1}+\theta_{t}+\sum_{j=1}^{k_{i}} \phi_{i, j} \Delta \pi_{i, t-j}+\varepsilon_{i, t}
$$

Different with the first method, in this formula we use $\pi$ as follow

$$
\pi_{i, t}=\frac{\pi_{i, t}}{\pi_{0 t}}
$$

Where $\pi_{0 t}$ is the numeraire city, Surabaya, $\Delta$ denotes the one-period (annual) change of a variable and $\theta$ represents a common time effect. $\varepsilon i, t$ is assumed to be a (possibly serially correlated) stationary idiosyncratic shock. The inclusion of lagged differences in the equation serves to control for serial correlation. As the sub index of $k$ indicates, we allow the number of lagged differences vary across individuals, whereby the respective number is determined using the top down approach suggested by Campbell and Perron (1991). The inclusion of a common time effect is supposed to control for cross-sectional dependence caused, e.g., by common fiscal policy shocks. To take control of this effect, we can transform the data by subtracting the cross-sectional mean leading to

$$
\Delta \tilde{\pi}_{i, t}=\rho \tilde{\pi}_{i, t-1}+\sum_{j=1}^{k_{i}} \phi_{i, j} \Delta \tilde{\pi}_{i, t-j}+\varepsilon_{i, t}
$$

Where is computed as

$$
\tilde{\pi}_{i, t}=\pi_{i, t}-\frac{1}{N} \sum_{j=1}^{N} \pi_{i, j, t}
$$

To see whether mean-reverting behavior in inflation rates is present, we test-following Levin and Lin (1993) - the null hypothesis that all $\rho_{i}$ are equal to zero against the alternative hypothesis that they are all smaller than zero, i.e., we test null hypothesis: 
$H_{0}: \rho_{1}=\rho_{2}=\ldots=\rho_{N}=\rho=0$

Against its alternative :

$$
H_{1}: \rho_{1}=\rho_{2}=\ldots=\rho_{N}=\rho<0
$$

If we can reject the null hypothesis of nonstationarity, inflation rates exhibit mean reverting behavior and thus any shock that causes deviations from equilibrium eventually dies out.

\section{RESULT AND ANALYSIS}

Our analytical results for cross sectional evidence are reported in table 1

\begin{tabular}{|l|l|l|l|}
\multicolumn{4}{c}{ Tabel III.1 } \\
\multicolumn{4}{|c|}{ Overall series (1983-2003) } \\
\hline \multicolumn{1}{|c|}{ Variable } & Coeficient & Std. Error & t-statistic \\
\hline constant & 454.5391 & 83.07407 & 5.471492 \\
$\pi i, t 0$ & -2.046214 & 0.863529 & -2.369594 \\
\hline
\end{tabular}

As a column two shows, the coefficient for overall series convergence coefficient has the correct sign and significant. Coefficient for $\pi i, t 0$ is negative, that is indicate convergence occurs in overall period (1983-2003). The value for the sub series, 1983-1993 and 1994-2003, is different from overall series. In first sub series period can be displayed as follow :

\begin{tabular}{l|l|l|l|}
\hline \multicolumn{4}{c}{ Tabel III.2 } \\
\multicolumn{4}{c|}{ Convergence Estimation Result in Period 1983-1993 } \\
\hline \multicolumn{1}{|c|}{ Variable } & Coeficient & Std. Error & t-statistic \\
\hline \multirow{2}{*}{ constant } & 101.1835 & 37.25102 & 2.716261 \\
$\pi i, t 0$ & -2.289101 & 1.432495 & -1.597982 \\
\hline
\end{tabular}

Coefficient for $\pi i, t 0$ is negative but not significant statistically. It is indicate that convergence is zero. Period 1994-2003 has the same results with the first sub series period, 1983-1993 that it has negative sign but not significant. The result is reported here:

Comparing the results for sub periods to those of total period is difference in convergence significance. It was indicates that price level in East Java region become convergence for longer time period (total sample period) than sub period sample since the Ordinary Least 


\begin{tabular}{l|l|l|l|}
\multicolumn{4}{c}{ Tabel III.3 } \\
\multicolumn{4}{c|}{ Convergence Estimation Result in Period 1983-2003 } \\
\multicolumn{1}{|c|}{ Variable } & \multicolumn{1}{|c|}{ Coeficient } & Std. Error & t-statistic \\
constant & 276.6833 & 47.17465 & 5.865083 \\
$\pi i, t 0$ & -0.032687 & 0.260496 & -0.125481 \\
\hline
\end{tabular}

Square (OLS) estimate of $b$ is negatively related to average change in the inflation rate over sample period.

In this section we will show the results from alternative method for price level convergence test. That is panel unit root test. In this method, because our sample period are very small we use one lag in all our test for single unit root test, just lag 1. if we use more lag to estimate unit root test, example lag 2, the result value for AIC and SC is similar. All equation we use are displayed in table 3 . Notice that the $36 \mathrm{t}$ - statistics for the null hypothesis $\rho \mathrm{i}=0$ have an average value -2.89385 . Since each series has 21 observation, the critical values at the 10 percent and 5 percent levels are about $-1,68$ and $-1,73$, respectively.

\begin{tabular}{|c|c|c|c|c|c|}
\hline \multicolumn{6}{|c|}{$\begin{array}{c}\text { Tabel III.4 } \\
\text { The Panel Unit Root Test For Regional Price Level }\end{array}$} \\
\hline Rural/City & t-stat & Rural/City & t-stat & Rural/City & t-stat \\
\hline bangkalan & -2.89383 & kab probo & -2.3864 & ngawi & -4.2097 \\
\hline banyuwangi & -3.16522 & kot blitar & -2.6261 & pacitan & -3.1437 \\
\hline bojonegoro & -4.13003 & kot kedri & -3.586 & pamekasan & -4.625 \\
\hline bondowoso & -4.11719 & kot madiun & -3.1883 & pasuruan & -2.6257 \\
\hline gresik & -0.83428 & kot malang & -1.6334 & ponorogo & -3.8014 \\
\hline jember & -5.30037 & kot mjkrto & -2.205 & sampang & -2.7528 \\
\hline jombang & -1.31004 & kot pas & -3.0199 & sidoarjo & -1.7867 \\
\hline kab blitar & -3.41134 & kot probo & -3.0891 & situbondo & -3.406 \\
\hline kab kediri & -4.55326 & lamongan & -1.0509 & sumenep & -0.9114 \\
\hline kab madiun & -1.34023 & lumajang & -2.9484 & trenggalek & -2.6688 \\
\hline kab malang & -1.9313 & magetan & -4.4484 & tuban & -1.8981 \\
\hline kab mjkrto & -4.30772 & nganjuk & -2.0013 & tulungagung & -2.8714 \\
\hline
\end{tabular}

Using panel unit root test, we found some problem about this method. Enders (2004) examines some problems as follows:

1. The null hypothesis for the Im, Pesaran, and Shin (IPS) test is $\rho i=\rho 2=\ldots=\rho n=0$. rejection of the null hypothesis means that at least one of the $\rho n$ is differs from zero. Thus it is 
possible for only one or two values of the $\rho n$ to differ from zero and still reject the null hypothesis. Unfortunately, there is no particular way of knowing which of the $\rho n$ are statistically different from zero. The results of the panel unit root test may be dependent on the choice of the time series variables included in the panel.

2. At this point, there is substantial disagreement about the asymptotic theory underlying the test. Sample size can approach infinity by increasing $n$ for given $T$, increasing $T$ for a given $n$, or by simultaneously increasing $\mathrm{n}$ and $\mathrm{T}$. Unfortunately, many of the important findings about the various tests are sensitive to this seemingly innocuous choice among the various assumptions. However, for small $\mathrm{T}$ and large $\mathrm{n}$, the critical values are dependent on magnitudes of the various $\varphi$.

3. The test requires that that error term from (4) be serially uncorrelated and contemporaneously uncorrelated. We need to determine the values of $k i$ to ensure that the autocorrelation of cit are zero. Nevertheless, the errors may be contemporaneously correlated in that $E \varepsilon_{i, t} \varepsilon_{j t} \neq 0$. If the regression residuals are correlated across equations, the critical values in table of panel unit root test are not applicable.

There are a number of other panel unit root tests in the literature. The Maddala-Wu (1999) test is similar to the IPS test but requires that you bootstrap our own critical values. The Levin-Lin-Chu (2002) test has the more restrictive alternative hypothesis $\rho i=\rho 2=\ldots=\rho n=0$. Nevertheless, the cautions listed above are applicable to all of the panel unit root tests.

\section{CONCLUSION}

The main objective of this paper was to study the nature of cross regional price dispersion in the East Java regions. We examined the dynamics of individual regions inflation rates ( $\beta$ convergence). Using two different methodologies, we are able to confirm that inflation rates of individual regions exhibit significant statistically mean reverting behavior. Thus, monetary authority, Bank Indonesia, does not has to be too worried about individual regions with temporarily high inflation rates. Differences in estimation results were found between total period and sub period when we used first method, cross-sectional evidence. In the total period we found that convergence coefficient had right sign and significant statistically, but in the sub period both in 1983-1993 and 1994-2003 the results are similar. Convergence coefficient in both result have the right sign and not significant.

According to second method of convergence estimation, we found the mean reverting of price level. With no time trend estimation we have an average value -2.89385 the critical values at the 10 percent and 5 percent levels are about $-1,68$ and $-1,73$ and it can be concluded 
that price level is mean reverting. Overall, the results of our analysis represents mostly good news for the Central Bank of Indonesia (BI), the good news are :

1. Regional inflation rates in East Java, hope nationally, do not drift apart but tend to meanrevert.

2. Overall dispersion has reached a presumably sustainable level.

3. The chosen inflation target does not excessively restrict the BI policy scope and seems to be compatible with the prevailing cross regional dispersion.

4. Deviation from Purchasing Power Parity (PPP) are not found, in other words the HarrodBalassa-Samuelson can not be proved.

The results, however, should be interpreted on the basis of number caveats. First, the evidence using provincial regions are very small part of the national regions, thus may be when we use national data the results are not mean reverting. Additionally, and more importantly, the BI should definitely try hard not let aggregate inflation increase or decrease below one digit. 


\section{REFERENCES}

Alberola E. and Tyrvainen T., 1998, Is There Scope for Inflation Differentials in EMU? An

Empirical Evaluation of the Balassa-Samuelson Model in EMU Countries, Bank of Finland.Discussion Papers.

Barro, R. J. and Sala-i-Martin, . (1995,. "Economic Growth". McGraw Hill,

Boston, MA.

Björkstén. Nils. 2000 . 'Real Convergence in The Enlarged Euro Area: A Coming Challenge for Monetary Policy'. Bank of Finland Economics Department Working Paper

BRUN, Jean-Fran®is, Jean-Louis COMBES, and Mary-Fran®ise RENARD,. 2003. 'Are there Spillover Effects between Coastal and Non-Coastal Regions in China ?'. CERDI-IDREC, draft Paper.

Canzonieri M., Cumby R., Diba B. and Eudey G., 1998, Trends in European Productivity:Implications for Real Exchange Rates, Real Interest Rates and Inflation Differentials, Oesterreichische Nationalbank Working paper, 27.

Cecchetti, S. G., Mark, N. C., and Sonora, R. (2000). Price level convergence among United States cities: Lessons for the European Central Bank. NBER Working

Paper Series No. 7681.

De Gregorio, I., and Wolf H.C., 1994, 'Terms of Trade, Productivity', and the Real Exchange. Rate, NBER Working Paper, n. 4807, Cambridge.

Enders. Walter, 2004. ' Applied Econometric Time Series '. USA. John Wiley \& Sons,Inc

Gruben William C. and Darryl McLeod. 2004 'Currency Competition and Inflation Convergence'. Center for Latin American Economics Working Paper 0204

Hyvonen. Markus,. 2004. ' Inflation Convergence Across Countries'. Research Discussion Paper, Economic Research Department, Reserve Bank of Australia.

Im K. S. , Pesaran M. H. and Shin Y., 1995, Testing for Unit Roots in Heterogeneous Panels, University of Cambridge, Department of Applied Economics Working Paper 
Kocenda. Eyzen. 'Inflation Convergence Within The European Union : A Panel Data Analysis. University of Houston, Houston, Texas, USA

Levin A. and Lin C. F., 1993, Unit Root Tests in Panel Data: New Results, University of

California, San Diego Department of Economics Working paper.

Libich. Jan. 2005. 'Rigidity and Commitment in Games: A Theory of Convergence to Low Inflation'.

Lefebvre, Mario and Stephen S. Poloz. 'The Commodity-Price Cycle and Regional Economic Performance in Canada'. Bank of Canada Working Paper 96-12.

Mentz, Markus and Steffen P. Sebastian, 2003. ' Inflation Convergence after the Introduction of The Euro'. Center For Financial Studies.

Nenna. Manuela, 2001. 'Price Level Convergence Among Italian Cities: Any Role for the Harrod-Balassa-Samuelson Hypothesis ?. Faculty of economics, University of Rome La Sapienza.

Ratfai Attila, 2003.' How Fast Is Convergence to the Law of One Price? Very (When Price

Differentials Are Properly Measured). Central European University

Weber. Axel A, and Guanter W. Beck. 2003. ' Price Stability, Inflation Convergence and Diversity in EMU : Does one Size Fit at All ?. CEPR and CFS working paper. 
470 Buletin Ekonomi Moneter dan Perbankan, Maret 2006

This page is empty on purpose 